RDA Toolkit

Essentials

http://www.rdatoolkit.org/essentials

Association for Library and Technical Services (ALCTS)

ALCTS offers several other webinars and webcasts. Many of the presentations are free.

For more information go to the ALCTS Webinar Archives:

http://www.ala.org/ala/mgrps/divs/alcts/confevents/past/webinar/index.cfm

\title{
SELECTED ARTICLES FROM CURRENT LIBRARY JOURNALS
}

Barrette, Linda. "Technical Services IS Public Service, or How I Got Out of the Back Room and Why You Should Too.” AALL Spectrum 16, no. 2 (November 2011): 20-22.

Boyd, Morag. "From the Comfort of Your Office: Facilitating Learner-Centered Continuing Education in the Online Environment." Cataloging \& Classification Quarterly 50, no. 2/3 (2012): 189-203.

Gardner, Sue Ann. "Cresting toward the Sea Change: Literature Review of Cataloging and Classification 2009-10.” Library Resources \& Technical Services 56, no. 2 (2012): 64-79.

Garofalo, Denise A. "Useful Web Sites for AV Catalogers.” Technical Services Quarterly 29, no. 2 (2012): 168-170.

Glennan, Kathryn P. "The Development of Resource Description \& Access and its Impact on Music Materials.” Notes 68, no. 3 (March 2012): 526-534.

Hoffman, Gretchen L. "Using the Quality Matters Rubric to Improve Online Cataloging Courses." Cataloging \& Classification Quarterly 50, no. 2/3 (2012): 158-171.

McCutcheon, Sevim. "RDA and the Reference Librarian: What to Expect from the New Cataloging Standard.” Reference Librarian 53, no. 2 (2012): 123-137.

Normore, Lorraine F. “'Here Be Dragons': A Wayfinding Approach to Teaching Cataloguing.” Cataloging \& Classification Quarterly 50, no. 2/3 (2012): 172-188. 
Oh, Dong-Geun. "Developing and Maintaining a National Classification System, Experience from Korean Decimal Classification.” Knowledge Organization 39, no. 2 (2012): 72-82.

Spidal, Debra F. "Treatment of Holocaust Denial Literature in Association of Research Libraries." Journal of Academic Librarianship 38, no. 1 (January 2012): 26-32.

Sullivan, Doreen. “Cataloging at Yale: Tools \& Resources.” Technical Services Quarterly 29, no. 2 (2012): 160-161.

Westrum, Anne-Lena, Asgeir Rekkavik, and Kim Tallerås. "Improving the Presentation of Library Data Using FRBR and Linked Data.” Code4Lib Journal 16 (2012-02-03).

http://journal.code4lib.org/articles/6424 (accessed April 18, 2012)

Wilson, Tiffany. "Videos_Cataloging (RDA) at Stanford University." Technical Services Quarterly 29, no. 2 (2012): 170-171.

Submitted by

Lynn Berg, Librarian for Technical Services

New Brunswick Theological Seminary (NJ)

Theology Cataloging Bulletin 